Evgenia Redkova

\title{
FEODOSY RUBTSOV`S CONTRIBUTION TO COMPARATIVE STUDIES \\ OF THE MUSICAL FOLKLORE OF SLAVS
}

\begin{abstract}
The Leningrad ethnomusicologist Feodosy Antonovich Rubtsov (19041986) in the 1960's was one of the leading experts in music folklore. The most significant works of the 1960's (Intonation Relations in the Songs of Slavs, The principles of mode construction in Russian Folk Songs, The semantic significance of cadences in Calendar Songs), which set out the concept of scales analysis and the theory of speech intonation, are based on the results studies of the calendar and wedding ritual folklore of traditions of Russian-Belarusian borderland.

The originality of the researcher's method lies in the fact that he uses the possibilities of comparative musicology in the study of tunes, revealing the commonality of intonations of musical folklore of the Slavs: Russian, Belarusian, Ukrainian, Polish, Serbian, Macedonian, Bulgarian and the others. The positions expressed once by Rubtsov on the basis of an analysis of Slavic folk songs regarding the speech nature of musical intonation were further developed, including in connection with the study of non-song forms of folklore.
\end{abstract}

Keywords: comparative musicology, scale, speech intonation, calendar and wedding songs, musical folklore of Slavs.

The researches of F. Rubtsov's ${ }^{1}$ are connected with the tasks of comparative study of scale and intonation properties of folk songs of the Slavs. In the monograph Intonation relations in the Songs of Slavs $(1962)^{2}$ the intonation relation of the folk melodies of the Slavs is revealed, the characteristic of the modal structures is given, the content of tunes is revealed through the semantics of the intonations which they are based on.

\footnotetext{
${ }^{1}$ Rubtsov Feodosy Antonovich (1904-1986) - composer, ethnomusicologist, professor at the Leningrad State Conservatory. The most significant works of the 1960's, which set out the concept of an analysis of scales and the theory of speech intonation, are based on the results studies of the calendar and ritual folklore of folk music traditions of RussianBelarusian borderland.

${ }^{2}$ In this article we will not separately consider the two works - the article „The Semantic Significance of Cadences in Calendar Songs“ (1962) and „The Principles of Mode Construction in Russian Folk Songs" (1964). But note that in them Rubtsov solves the problems of determining the scale and he characterizes the angemitonic, diatonic (simple and complex) systems, while emphasizing the ritual semantics of cadences of folk songs. The research also contains a comparative aspect: Rubtsov compares examples of traditional folk songs of Russian, Belarusian with Bulgarian, Serbian and other people.
} 


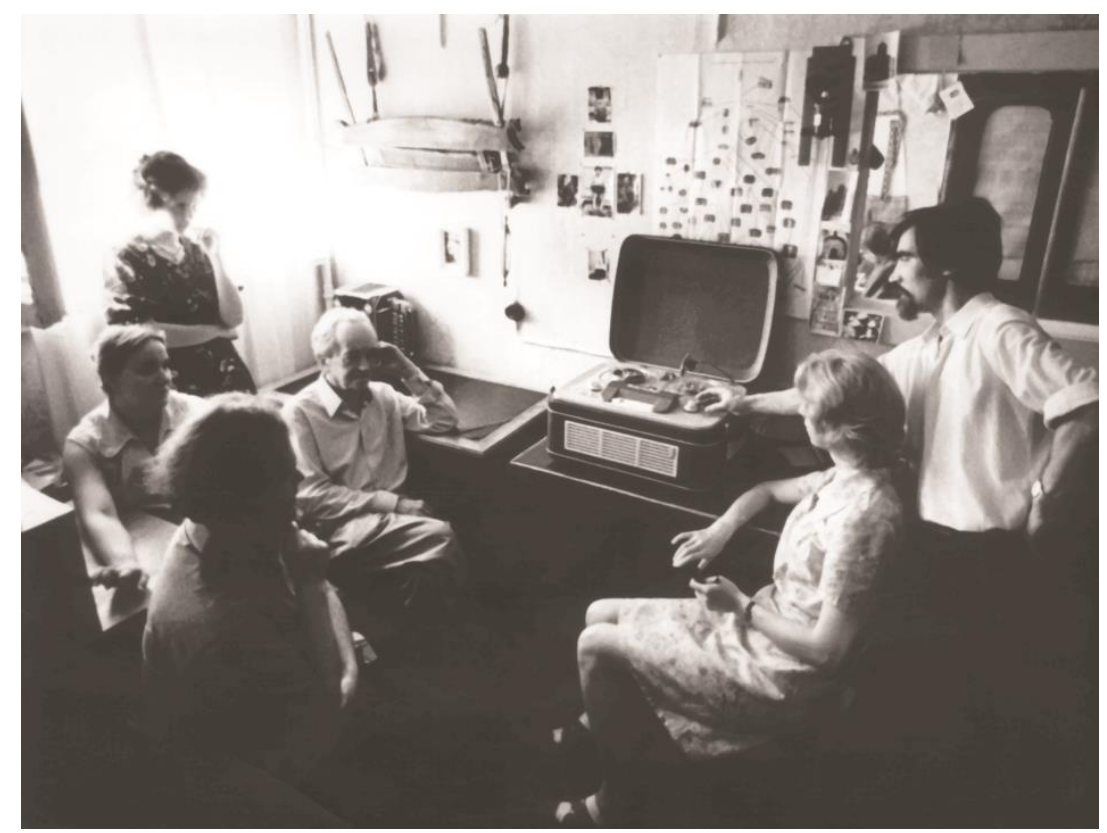

Photo 1. Rubtsov with students and colleagues at the Laboratory of Folk Musical Creativity of the Saint-Petersburg Rimsky-Korsakov State Conservatory

In studying folk music the researcher, first of all, is basing his research on the knowledge of the traditions of the Russian-Belarusian borderland. Let us emphasize that the scientific interest in folklore by Rubtsov was formed gradually, including the basis of children's and youth impressions, and they are connected with the song tradition of the small homeland - the village Olsha Mogilev in the region of Belarus. The first hearing notations of folk songs Rubtsov made in the 1920's, and the first scientific experience in the field of ethnomusicology he received after graduating from the Leningrad Conservatory thanks to his knowledge of the Belarusian language and the skills of musical decryption of folk songs.

Rubtsov recalled the beginning of folkloristic activity: "Since childhood I loved and knew the folk song. From 1936, I began to collect, study and arrange folk songs systematically. Mostly my work was carried out under the leadership of Eugeny Gippius under the Folklore Commission of the Peoples of the USSR Institute of Anthropology, Ethnography and Archaeology of the Academy of Sciences of the USSR. From 1938 to 1941 I systematically worked on recording the Belarusian folk songs, performing a number of assignments and works for the Academy of Sciences of the Belarusian Soviet Socialist Republic. I participated in four expeditions (1937 - Vologda region, 1938 - Smolensk region, 1939 - Belarus, 1941 - Pskov region)" (Archive of the Saint-Petersburg Rimsky-Korsakov State Conservatory. Folder № 233. Personal file of F. A. Rubtsov, 01.09.1985. P. 43).

The results of this work were reflected in the publications with the participation of F. A. Rubtsov: the first volume of Folk Songs of the Belarusians (1940), Folk Songs of the Ethos's of the USSR. Belarusians (1941). 
For the first time in Rubtsov's legacy, comparative study of folk songs of the Slavs was undertaken in the educational and methodological development of the early 1950's Anthology on Folk Musical Creativity which was never published. The manuscript of anthology includes samples of various genres of musical folklore from Archangelsk, Vologda, Leningrad, Pskov, Smolensk, Oryol, Voronezh and other regions of Russia, as well as Belarus (about 100 examples in total). Rubtsov groups songs by genre, highlighting three major sections:

1) Songs of the annual farming circle, as well as their related game and round dances;

2) Songs related to family life;

3) Epic songs.

Of our particular interest is the first section of the anthology devoted to the calendar and ritual folklore, as the oldest in the historical and stylistic terms. Intonation analysis of calendar songs according to Rubtsov makes it possible to get closer to understanding one of the most important issues of ethnomusicology specificity of national tunes: "The establishment of at least in the most general features of the intonation basis of this oldest song layer available to our observation is of particular interest, because only having realized such intonation basis, we will be able to somehow understand the following diverse song forms and trace the complex path of a kind of national Russian melodies" (Archive of the Mekhnetsov Folklore and Ethnography Center of the Saint-Petersburg Rimsky-Korsakov State Conservatory. The manuscript fund of F. A. Rubtsov. Folder 5. Unit of storage 08. Sheet 15).

Analysis of the genres of calendar and ritual musical folklore Rubtsov begins with carols. He notes the festive nature of their sound, the connection with ancient ideas about the possibility of magical impact of man on nature, identifies typical variants of the plot motifs of poetic texts, points out the rhythm features that indicate the possibility of performing carols with elements of dance movements. We emphasize that the carol melodies are diverse due to the specifics of local traditions. However, Rubtsov discovers a common melodic beginning in a whole group of tunes. "In the melodic structure of holy congratulatory songs, there is often a melody based on the descending diatonic pentachord of major inclination. ... Such 'popevka' ${ }^{3}$ which developed from an archaic scale 'inverted' tetrachord in the fifth is the main one for a certain tradition of wedding songs..., it often is present at 'volochebny' songs ${ }^{4} \ldots$ This observation, confirmed by the analysis of a number of

\footnotetext{
3 "Popevka" is the term of the ancient Russian theory of music, which is currently used in the study of musical folklore and even composer music. In Rubtsov's works, it is a form of realization of speech intonations, it has completeness in semantic terms, it is understood as a structural part of a song's melody. For the interpretation of the term and its application in Russian musicology, see: (Королькова, 2010, 70); (Булычева, 2015, 146-157).

${ }^{4}$ These are goodwill songs that were performed during house walks on Easter. Those who sang them gave eggs, pies. By function and place in the rites of Easter are similar to Christmas carols.
} 
song samples taken from different sources, allows to assume some intonation commonality in the structure of congratulatory Christmas carol greeting songs (winter holidays), Easter greeting songs (spring holidays) and a number of wedding songs related to the festive side of the rite" (Archive of the Mekhnetsov Folklore and Ethnography Center of the Saint-Petersburg Rimsky-Korsakov State Conservatory. The manuscript fund of F. A. Rubtsov. Folder 5. Unit of storage 08. Sheet 23).

The presented ideas were used in the monograph Intonation Relations in the Songs of Slavs:

1) The process of the formation of Russian melody can be revealed only if the intonation basis of the songs of the archaic layer is determined;

2) In the melodic structure of carols, "popevkas" based on the descending diatonic major pentachord are often found;

3) This "popevka" developed on the basis of the archaic sound of the tetrachord in the quintus, it is also characteristic of wedding songs, as well as songs that are sung during the arrival of houses at Easter and Christmas.

The work became not only the first major scientific work published by Rubtsov but also one of the first monograph in domestic ethnomusicology devoted to a comparative study of traditional folk songs of Slavs.

During the analysis of song folklore Rubtsov pays special attention to speech intonation $^{5}$, the content of which is revealed through a melody contour (at this level rhythm plays a supporting role, emphasizes the melodic line). The scientist takes a search for common Slavic intonations in the most ancient genres (these include calendar and wedding songs chosen for analysis), the tunes of which base at the short musical phrases. Based on the methods of comparative analysis, Rubtsov identifies commonality in the tunes of Slavs (Russians, Belarusians, Ukrainians, Poles, Serbs, Macedonians, Bulgarians and others), characterizes modal structures, interprets the content of tunes, through the meaning of intonations.

At the first stage of the study, Rubtsov studies the tunes of wedding songs from Belarus, which belong to the same structural-rhythmic type, but are related as melodic variants ${ }^{6}$.

\footnotetext{
${ }^{5}$ Rubtsov indicates the work of V. Vsevolodsky-Gerngross, The Theory of Russian Speech Intonation (Всеволодский-Гернгросс, 1922, 1-128), he was also well acquainted with the works of B. Asafiev on intonation and "popevka". About the formation of Asafiev's intonation theory, see (Орлова, 1984, 1-302).

${ }^{6}$ A wedding tune with the structure of a verse of $5+3$ syllables and rhythmic selection of the last syllable of each syllable group is widespread among the Eastern Slavs.
} 


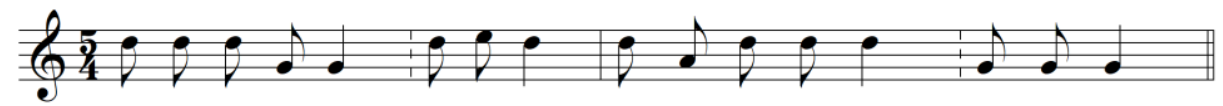

1.Раз го - ре - ла - ся ка - ли - на, раз - го - ре - ла - ся ка - ли - на.
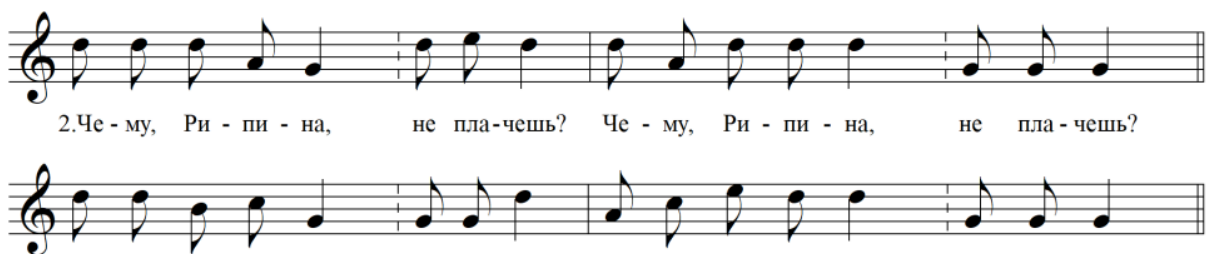

4.Не стой, бо - жу - хна, под о-кном, не стой, бо - жа - хна, под о - кном.

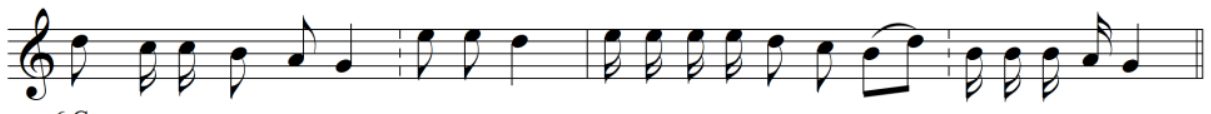

6.Стук-ну -ло, трюк-ну - ло на дво-ре, по-гля-ди -ка, ма - му - хна, ти не по мя -не.

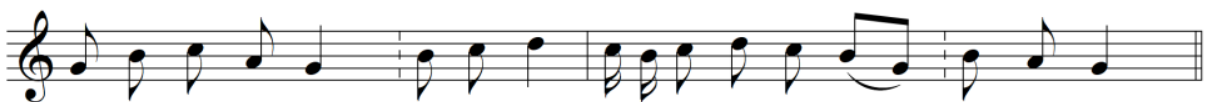

8.А в су - ббо - то - чку по-здне-нько ко-ва-ли ко - ва - ли ро - зне - нько.

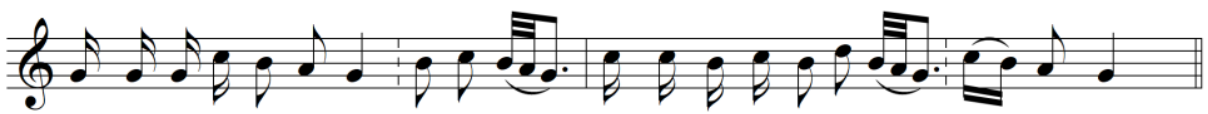

10.Ти бо-гат ты, зя-тю-хна, ти бо-гат, мно-го ль ма-ешь ко-ни-ков, же - ре - бят.

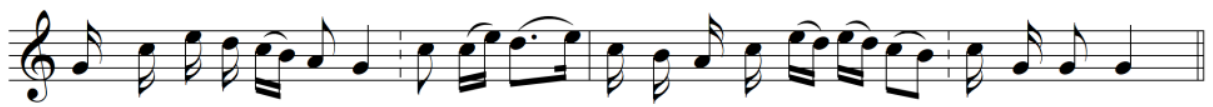

11.На д(ы)-во-ре ду - до-чка и - гра-ет, там Во-ло-дька ко - ни - ка се-д(ы)-ла - ет.

Example 1. Wedding songs (Rubtsov, 1962, 29)

The researcher identifies such structural features of the tunes as the presence of 4 melodic phrases ("popevkas") and downward movement in the range of the fifth.

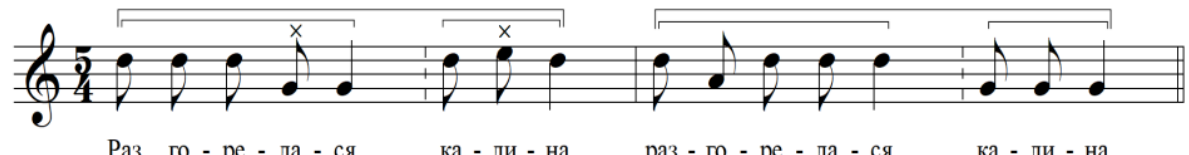

Rubtsov generalizes the structure of the scale, shows the ratio of the main and secondary supports of wedding melodies as follows:

Example 2. The variants of scales of wedding songs (Rubtsov, 1962, 32) ${ }^{7}$.

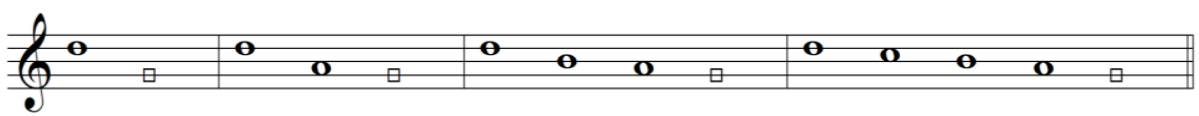

${ }^{7}$ The square indicates the main reference tone of the scale. 
Rubtsov concludes that such a contour of tune is consistent with a bright, festive musical form, and is associated with the intonation of the exclamation. The scientist suggests that similar in structure and character of the song can be used not only in weddings, but also in other ancient rites of the Slavs.

Rubtsov compares the tunes of wedding ceremonial songs with carols.

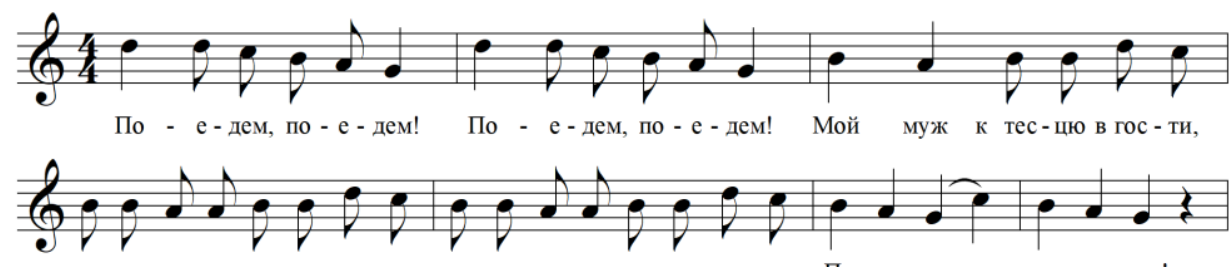

а мо-ло-да да к та-туль-ке, дет-ки мо-и дак де-дуль-ке. По - е - дем, по - е - дем!

Example 3. Carol (Rubtsov, 1962, 43).

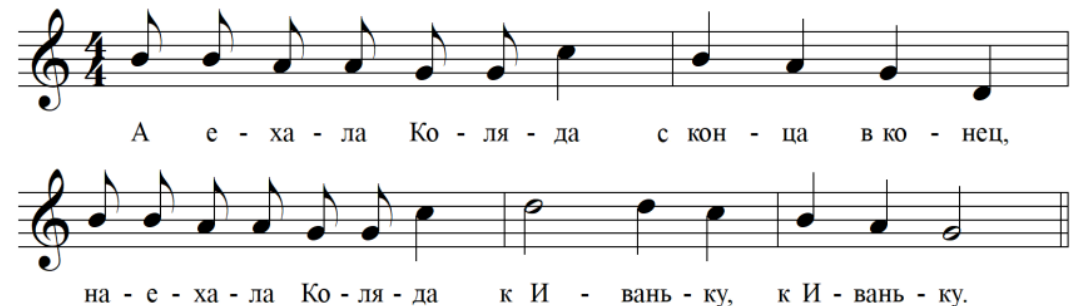

Example 4. Carol (Rubtsov, 1962, 43).

The source for a comparative study of T. Rubtsov was the tunes published at the end of the 19th - first half of the 20th centuries by Serbian, Bulgarian, Czech, German, Polish collectors and scientists (M. Vasilevich, V. Stoin, K. Tsarnushanov, K. Erben, G. Beem, J. Roger, A. Khibinsky, etc. $)^{8}$.

Here are a few examples of carol and wedding songs, that Rubtsov includes for comparative analysis from the publications of K. Kvitka, V. Stoin, K. Tsrnushanov.

\footnotetext{
${ }^{8}$ Rubtsov uses sample songs from the following publications: Стоин В. Народни песни от Тимок до Вита (1928); Стоин В. Народни песни от Средна Северна България (1931); Църнушанов К. Македонски народни песни (1956); Василевић М. Југославенски музички фолклор. I. Космет (1959); Василевић М. Југославенски музички фолклор. II. Makedonija (1953); Станкевич Ж. Народне песме Крајине (1951); Erben K. J. Prostonárodní české písně a řikadla (1864); Bim G. Zpevnik narodnich pisni (1946); Slovenske ljudske pesmi (1950, 1952, 1956); Roger J. Piosenki Polaków (1863); Chybiński A. Od Tatr do Battyku. Śpiewnik krajoznawczy (1950); Н. А. Римский-Корсаков Сто русских народных песен (1877); Белорусские народные песни (1941); Песни белорусского народа (1940); Труды Музыкально-этнографической комиссии (1906); Народні мелодіi з голосу Л. Украінки, записав і упорядив К. Квітка (1918). Rubtsov also included songs he had recorded by ear in the Smolensk region in the 1920s, and auditory notations by N. Yanchuk, I. Zubov (Mogilev region) and A. Petrov (Minsk region).
} 


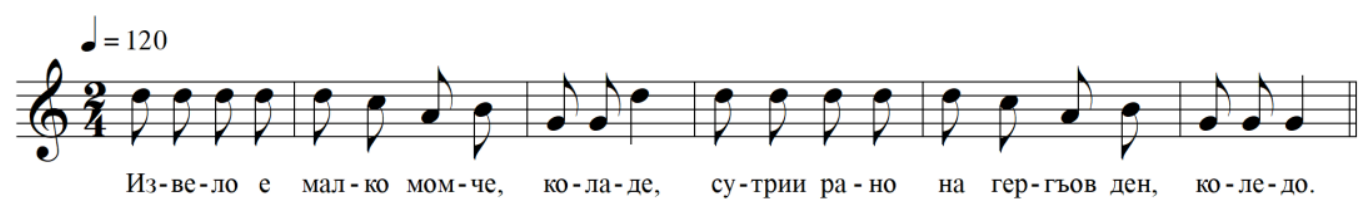

Example 5. The Bulgarian carol (Rubtsov, 1962, 86).
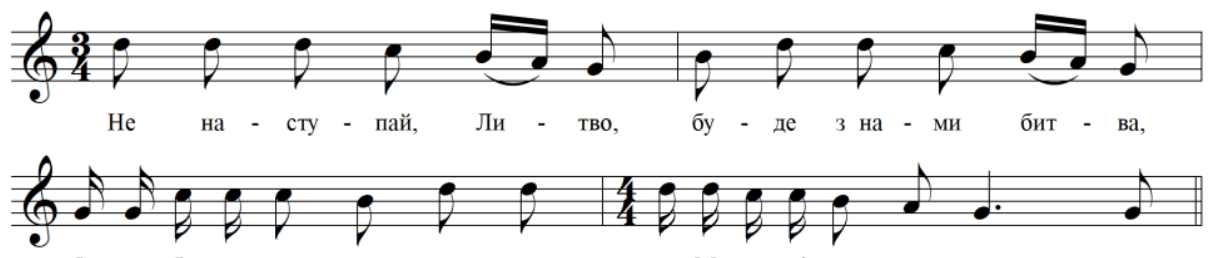

бу-дем би - ти, во - ю - ва - ты, та Ма-ры-сі не да - ва - ти.

Example 6. The Ukrainian wedding song (Rubtsov, 1962, 59).
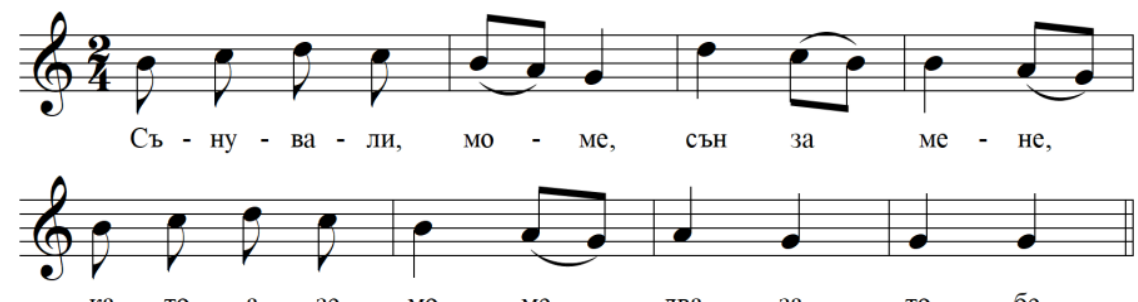

Example 7. The Bulgarian wedding song (Rubtsov, 1962, 83).

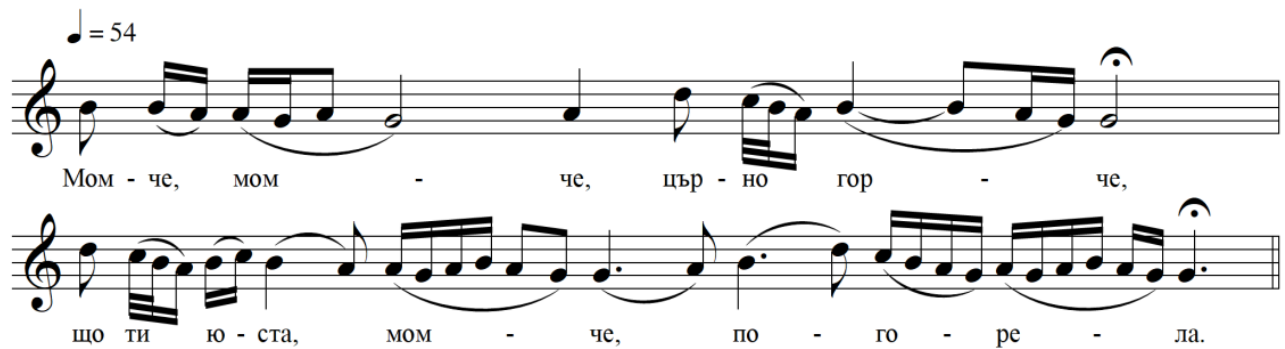

Example 8. The Macedonian wedding song (Rubtsov, 1962, 88)

The approach of Rubtsov was criticized by the famous musicologist Vladimir Goshovsky in the scientific "At the Origins of Folk Music of Slavs" (1971). Goshovsky did not agree with several positions, in particular, with the choice of "popevkas" and simple one-phrase melodies as correlated during the analysis. Referring to the experience of comparative study of the music of Slavs of Kliment Kwitka, undertaken in the article "On the Areas of Distribution of Certain Types of Belarusian Calendar and Wedding Songs", Goshovsky stressed the importance of studying song types. He considered that is unacceptable to neglect structural and rhythmic parameters in the analysis of songs of Slavs (Гошовский, 1971, 33-35). 
The impact of Kvitka's researches ${ }^{9}$ on Rubtsov's scientific heritage, with all the difference in approaches, seems quite significant. Rubtsov knew Kvitka's articles well, as evidenced by the links in his publications. Without disputing Kvitka's approach, Rubtsov also chooses the direction of research - comparative Slavic studies, often for analysis uses the same or very close material (not only regionally, but also typologically), pays considerable attention to the genres of calendar and ritual (in particular, carols) and wedding musical folklore and issues of their modal organization. However, Rubtsov's ideas and scientific and analytical conclusions are being developed in a different way and represent an independent point of view on similar problems.

Rubtsov assessed his work not as a completed concept, but as an initial scientific and research development, in which he sought to identify the reasons for the intonation connections of folk songs of Slavs, to develop methods of highlighting common signs of melodies.

But what is the core of his concept of the intonation community of Slavs? Rubtsov based his research on the thesis of the kinship of Slavic languages and the stages of their development, which were made in the field of comparative historical linguistics and he applied it to musical folklore. Rubtsov noticed that "In the X-XI centuries, judging by the ancient Slavic monuments, the Slavic languages differed from each other no more than dialects of the same language" (Rubtsov, 1962, 9). He believed that the process of forming the musical language of the Slavs in the early stages of the formation of cultures took place according to similar principles.

The formation of the simplest musical phrases is closely related to speech intonation, the possible primary form of manifestation of which in music is a "popevka" that serves as the basis of the simplest tunes.

Speech intonation shows itself through the melodic line and it is recognized by us as an exclamation (or calls), lamentation (as lament) and narrative. These intonations can complement the meaning of words, but can also be understood without words.

Studying the songs of the Slavs, different in structure, but similar in intonational contour, Rubtsov came to understand the universal phenomena in music coming from antiquity - the possibility of understanding the meaning, nature of sound, which is inherent in tunes and musical intonations.

Rubtsov's scientific studies had a significant impact on subsequent research in the study of scale of folk songs (Земцовский, 1975, 1-224). The method of studying the modal structure of the tunes in connection with its structure from the musical phrases "popevok" allows us to observe the process of formation of the fret, to identify the "intonational vocabulary", to interpret the content of songs based on

\footnotetext{
${ }^{9}$ Let us indicate several Kvitka's articles: "Songs of Ukrainian winter ceremonial festivals" (Квитка, 1971, 103-155), "On the Historical Significance of Calendar Songs" (Квитка, 1971, 73-100), "On Areas of Distribution of Some Types of Belarusian Calendar and Wedding Songs" (Квитка, 1941, 123-131). The comparative aspect is most fully presented in publications Slavic Pentatonics (Квитка, 1971, 286-308) and Phenomenon of Commonality in the Melody and Rhythm of Bulgarian Folk Songs and Songs of Eastern Slavs (Квитка, 1971, 191-212).
} 
the meaning of their intonations. Intonation and semantic analysis turned out to be productive in the study of "non singing" (do not have the form of a song) genres of musical folklore (for example, lamentations, calls), but also in addressing issues of genre and style assessment and identifying the genetic relationships of musical folklore samples (Лобкова, 2000, 1-223).

\section{LITERATURE}

БУЛЬЧЕВА, А. В. (2015). Могут ли ‘попевки’ быть ‘бородинскими’? О возможности применения термина 'попевка' к композиторской музыке нового времени. Научный вестник Московской консерватории, № 1., Москва.

ВСЕВОЛОДСКИЙ-ГЕРНГРОСС, В.Н. (1922). Теория русской речевой интонации. Государственное издательство, Петроград.

ГОШОВСКИЙ, В. Л. (1971). У истоков народной музыки славян: Очерки по музыкальному славяноведению. Москва: Советский композитор, 1-304.

ЗЕМЦОВСКИЙ, И. И. (1975). Мелодика календарных песен. Ленинград: Музыка, Ленинградское отделение, Ленинград.

КВИТКА, К. В. (1971а). Ангемитонные примитивы и теория Сокальского. Избранные труды: В 2-х томах, том 1. Советский композитор, Москва.

КВИТКА, К. В. (1971b). Об историческом значении календарных песен. Избранные труды: В 2-х томах, том 1. Советский композитор, Москва.

КВИТКА, К. В. (1941). Об областях распространения некоторых типов белорусских календарных и свадебных песен. Белорусские народные песни. Ленинград, Музгиз, Минск.

КВИТКА, К. В. (1971). Песни украинских зимних обрядовых празднеств. Избранные труды: В 2-х томах, том 1. Советский композитор, Москва.

КВИТКА, К. В. (1971). Явления общности в мелодике и ритмике болгарских народных песен и песен восточных славян. Избранные труды: $B$ 2-х томах, том 1. Советский композитор, Москва.

КОРОЛЬКОВА, И. В. (2010). Лирические песни в традиционной культуре Северо-Запада России, Государственный республиканский центр русского фольклора, Москва.

ЛОБКОВА, Г.В. (2000). Древности Псковской земли: Жатвенная обрядность: Образы, ритуалы, художественная система, Министерство культуры Российской Федерации, Государственное учреждение культуры „Фольклорно-этнографический центр“, Санкт Петербург Дмитрий Буланин, Санкт-Петербург.

ОРЛОВА, Е. М. (1984). Интонационная теория Асафьева как учение о специфике музыкального мышления: История становления и сущность. Музыка, Москва.

РУБЦОВ, Ф. А. (1962). Интоначионные связи в песенном творчестве славянских народов: Опыт исследования, Советский композитор, Ленинград.

РУБЦОВ, Ф. А. (1964). Основы ладового строения русских народных песен, Музыка, Ленинград. 
РУБЦОВ, Ф. А. (1962). Смысловое значение кадансов в календарных песнях. Вопросы теории и истории музыки: Сборник статей, выпуск 1., Музыка, Ленинград.

Евгенија Редкова

\section{ПРИЛОГ КОН КОМПАРАТИВНОТО ПРОУЧУВАњЕ НА ТЕОДОСИЈ РУБЦОВ ЗА МУЗИЧКИОТ ФОЛКЛОР НА СЛОВЕНИТЕ}

\section{Резиме}

Ленинградскиот етномузиколог Теодосиј Антонович Рубцов (1904 - 1986) во 60-тите години од 20 век беше еден од водечките специјалисти за музички фолклор. Најзначајните дела од 60-тите години на минатиот век (Интонаииски врски во словенските песни, Основи на модалната структура на руските народни песни, Семантичкото значење на каденциите во календарските песни), во кои е утврден концептот на модална анализа и теоријата на интонацијата на говорот, развиени врз проучување на примери од календарен и свадбен фолклор на народни музички традиции на руско-белоруската погранична област.

Специфичноста на методата на истражувачот е во тоа што тој ги користи можностите за компаративна музикологија при проучувањето на мелодиите, откривајќ ја заедничката интонација на музички фолклор на Словените: Руси, Белоруси, Украинци, Полјаци, Срби, Македонци, Бугари и други. Ставовите изразени од Рубцов, врз основа на анализата на народните песни во однос на говорната природа на музичката интонација, беа понатаму развиени, вклучително и во врска со изучувањето на формите на песни што не се пеат, а егзистираат во фолклорот. 